\title{
Investigating the diamond potential of southern West Greenland
}

\author{
Sven Monrad Jensen and Karsten Secher
}

Southern West Greenland hosts a province of ultramafic alkaline rocks, including swarms of dykes traditionally described as kimberlites and lamproites (Larsen 1991; Jensen et al. 2002). Since the mid-1990s, commercial diamond exploration has been focused on the Sarfartoq region and the region south-east of Maniitsoq (Fig. 1), and has resulted in numerous reports of diamond-favourable indicator minerals from till sampling, finds of kimberlitic dykes, and recovery of diamonds from kimberlitic rocks.

A new digital compilation of company data released from confidential status (Jensen et al. 2003a) presents a comprehensive overview of exploration activities and results that have emerged since the Survey's first compilation of occurrences of kimberlitic and related rocks (Larsen 1991). The new compilation in a GIS (geographic information system) environment allows for refined assessment of the distribution, structural control and possible spatial and petrogenetic relationships that characterise the kimberlitic occurrences.

In 2003, the Geological Survey of Denmark and Greenland (GEUS) and the Government of Greenland's Bureau of Minerals and Petroleum (BMP) went further than has been customary in investigating the economic potential of specific sites. Four areas were temporarily closed to application for exploration licences, pending sampling and testing for diamond content of large samples of more than one tonne each from significant kimberlitic occurrences. Additional characterisation and research initiated on these and other occurrences include magnetic mapping, detailed petrography and studies of mantle xenoliths, as well as indicator mineral chemistry. An extensive programme to determine the ages of kimberlitic and related rocks was also initiated in 2003.

\section{Distribution of kimberlitic occurrences}

Alkaline ultramafic dykes in the Sisimiut-Kangerlussuaq and Sarfartoq regions intrude the border zone between the Archaean craton and the Palaeoproterozoic Nagssugtoqidian orogen (Fig. 1; Secher \& Larsen 1980). The occurrences south-east of Maniitsoq mark the southernmost extent of the alkaline province.

The alkaline rocks of interest here have previously been described as kimberlites and lamproites (Larsen 1991; Jensen et al. 2002). This classification was questioned by Mitchell et

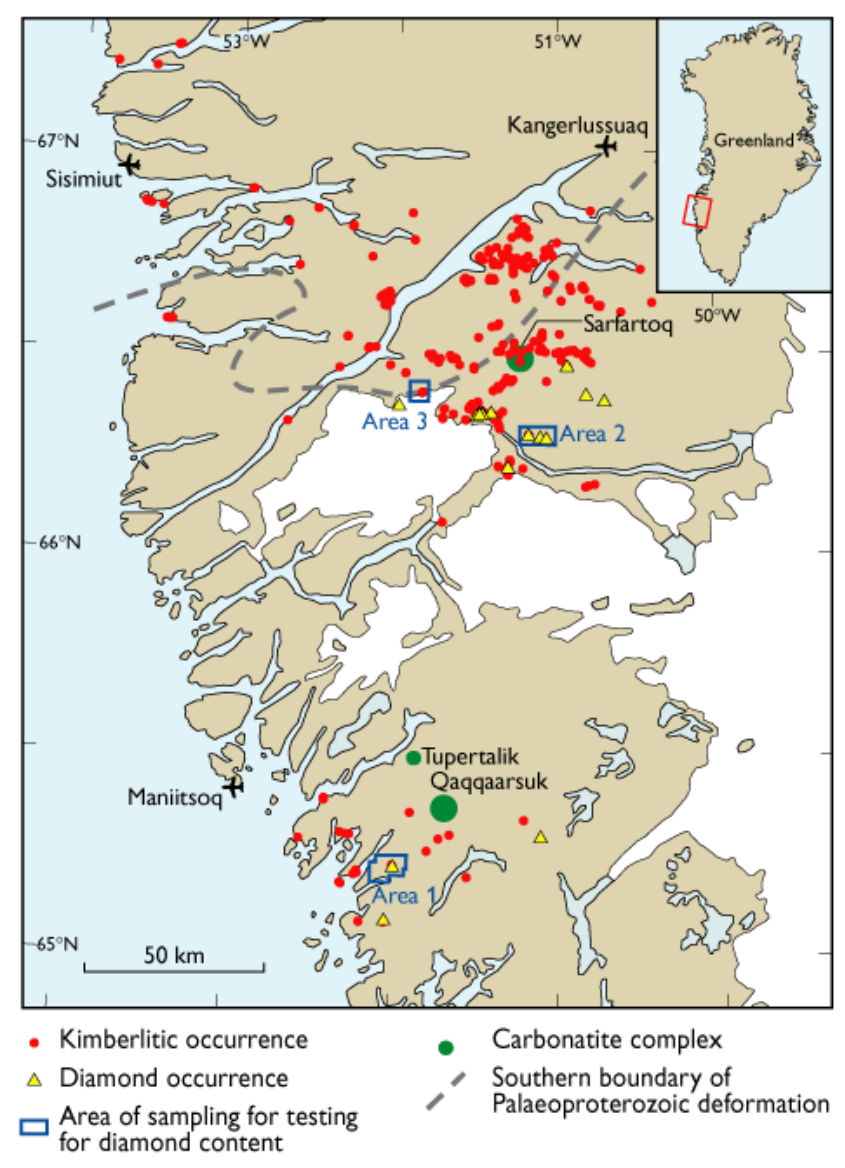

Fig. 1. Map of kimberlitic and diamond occurrences of the West Greenland alkaline province. Framed areas enclose the three kimberlitic occurrences sampled for determination of diamond content in 2003.

al. (1999), who consider that they are not typical kimberlites, but unusual ultramafic lamprophyres in that they are sometimes diamondiferous. In the absence of petrographic data for many of the occurrences the broader terms 'kimberlitic' and 'lamproitic' are applied here.

Three clusters of dykes have been recognised within the province during the last 20-30 years (Larsen 1980, 1991; Scott 1981). The 'Sisimiut cluster', consisting mainly of 1214-1240 Ma lamproitic and c. 590 Ma kimberlitic dykes (Larsen \& Rex 1992), is characterised by vertical E-W to SE-NW trends. The 'Sarfartoq cluster' has been described as a cone-sheet structure centred on the $600 \mathrm{Ma}$ Sarfartoq car- 


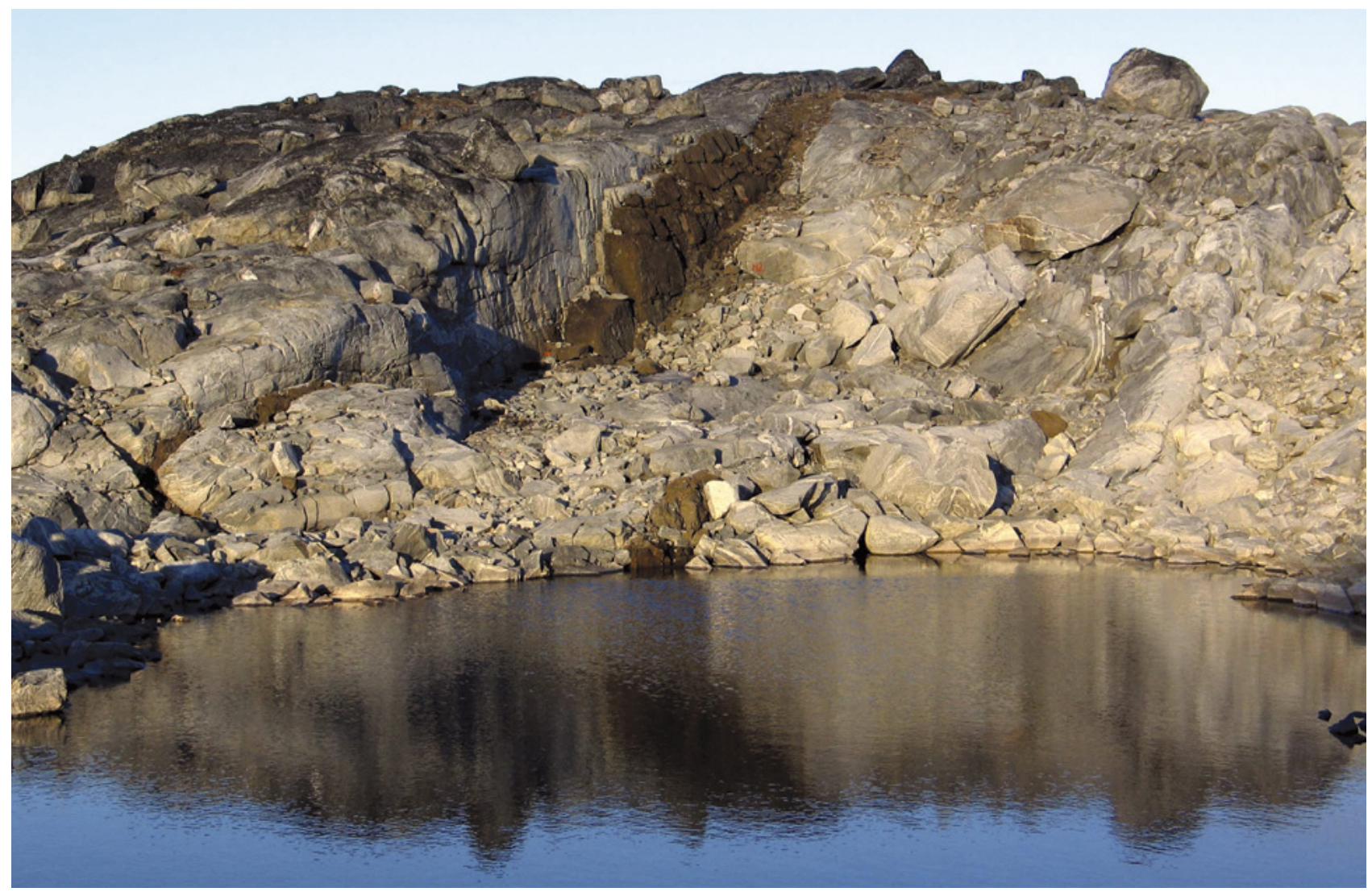

Fig. 2. Outcrop of one of the three kimberlitic occurrences from which more than $1000 \mathrm{~kg}$ of rock was collected (Area 1 in Fig. 1). Width of dyke approx. $1 \mathrm{~m}$.

bonatite complex (Larsen 1980). The $600 \mathrm{Ma}$ kimberlitic dykes of the 'Maniitsoq cluster' have more variable orientations.

The cone-sheet model for kimberlitic dykes around the Sarfartoq carbonatite complex was largely based on dyke orientations in a broad $\mathrm{E}-\mathrm{W}$-trending valley transecting the core of the complex. With new knowledge of hundreds of additional kimberlitic occurrences in the region presented in Jensen et al. (2003c), it now appears that other structural elements have controlled the emplacement of dykes. For example, some kimberlitic dykes follow the trends of the Palaeoproterozoic Kangâmiut dolerite dykes, as outlined by Escher et al. $(1970,1976)$, in reworked as well as unreworked parts of the Archaean basement. Another example is an apparent predominance of $\mathrm{N}-\mathrm{S}$-trending kimberlitic dykes in a zone reaching far beyond the Sarfartoq carbonatite complex. Information from magnetic field data lends support to the hypothesis that kimberlitic dyke emplacement may be controlled by structures of regional character (Jensen et al. 2003b, c).

\section{Digital compilation of data}

Exploration companies have produced a large volume of data relevant to diamond exploration, especially since 1994 . The data include analyses of heavy minerals from till and stream sediment samples, dyke and boulder distribution maps, airborne and ground geophysical surveys, results of testing for diamond content of mini-bulk sampled dykes, drill logs, etc.

A GIS compilation of company exploration data now in the public domain (Jensen et al. 2003a) constitutes the most extensive overview of kimberlitic rocks and diamond occurrences in Greenland to date. The compilation contains scanned text and maps, and selected digital data from company assessment reports submitted to BMP in fulfilment of the standard terms for mineral exploration licences. A total of 146 company reports of relevance to diamond exploration, with a total of approximately 9250 pages of text, tables and maps, are included as PDF files. More than 53000 tabulated analyses of indicator minerals from till and stream sediment are available, as are the details and results of drilling campaigns and tests for diamond content. 


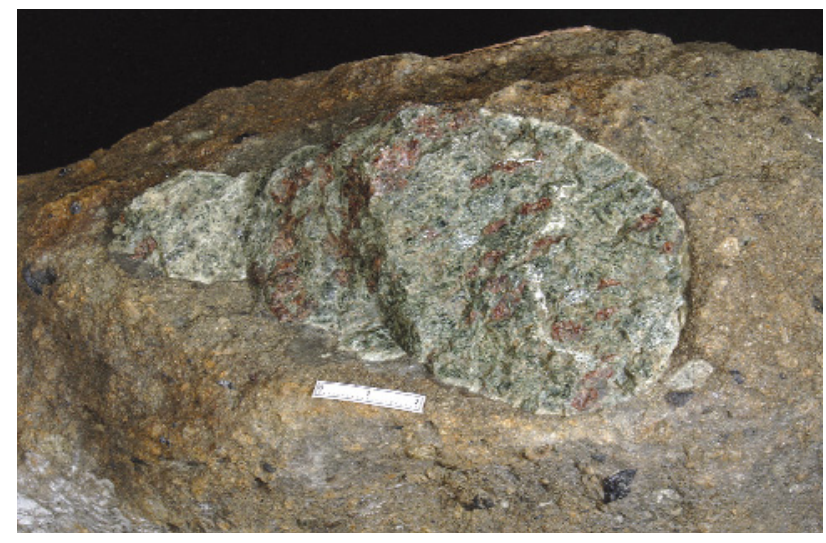

Fig. 3. Eclogitic xenolith in one of the dykes sampled for testing for diamond content (Area 1 in Fig. 1). Scale bar is $2 \mathrm{~cm}$.

\section{Diamond occurrences and indicator mineral chemistry}

Most of the approximately 600 diamonds reported to date in Greenland are from just two areas, both located in the unreworked Archaean craton (Jensen et al. 2003a). Some 95\% of the stones are classified as microdiamonds, i.e. smaller than the minimum size recoverable in operating mine plants - typically those passing a $0.5 \mathrm{~mm}$ screen. Another 20 microdiamonds from kimberlitic occurrences to the west of the Sarfartoq carbonatite complex were reported in late 2003 (Tuer 2003). The largest diamond from an in situ dyke reported to date is $c .1 .7 \mathrm{~mm}$ in its longest dimension and has a weight of around 0.001 carat $(1$ carat $=0.2 \mathrm{~g})$. Although microdiamonds do not constitute an economic resource, they are important to the characterisation of kimberlites and evaluation of diamond deposits (Rombouts 1995).

Nearly all of the reported diamonds have been recovered using caustic dissolution, a method that is usually adjusted to recover stones of all sizes down to around 0.1 or $0.15 \mathrm{~mm}$. In addition, a few diamonds have been found in large stream sediment samples. Some occurrences have also been subjected to dense media separation tests for larger diamonds, where up to 11 tonnes of kimberlitic rock have been processed (Boucher 2000), but none of these tests have recovered any diamonds.

All in situ diamond occurrences lie within areas outlined by diamond-favourable indicator minerals from till and stream sediment samples. On a local scale, however, kimberlite tracing using indicator minerals from till samples is not straightforward, probably due to the influence of complex glacial dynamics on the formation of the till deposits. The most diamond-favourable indicator minerals are distributed far beyond the areas with known diamonds. This observation, together with the postulated regional structural con- trols, suggests that the potential for diamonds is not restricted to the known occurrences. The potential appears to exist on both sides of the boundary between reworked and unreworked Archaean basement.

\section{Testing of three kimberlitic occurrences for diamond content}

In 2003, GEUS and BMP undertook sampling of three large occurrences of kimberlitic rocks for subsequent testing for diamond content using caustic dissolution.

Composite samples of approximately $1000 \mathrm{~kg}$ from each occurrence have been processed and examined for diamonds by a certified Canadian testing laboratory. Two of the occurrences are vertical dykes with a length of approximately $2500 \mathrm{~m}$ and a width of up to $2 \mathrm{~m}$ (Figs 2-4). The third occurrence is a shallow-dipping sill with a length of at least $500 \mathrm{~m}$ and a thickness of 1-2 m. The sill and one of the long dykes lie well within the unreworked Archaean craton, while the second long dyke lies a few kilometres inside the Palaeoproterozoic deformed region (Fig. 1).

The test resulted in 125 diamonds recovered from the sampled dyke in Area 1 (Fig. 1), two diamonds from the dyke in Area 2 and one diamond from the dyke in Area 3 (Jensen et al. 2004). The largest diamond recovered measures $0.74 \times$ $0.63 \times 0.54 \mathrm{~mm}$, and the total weight of the 128 stones is 0.016 carat.

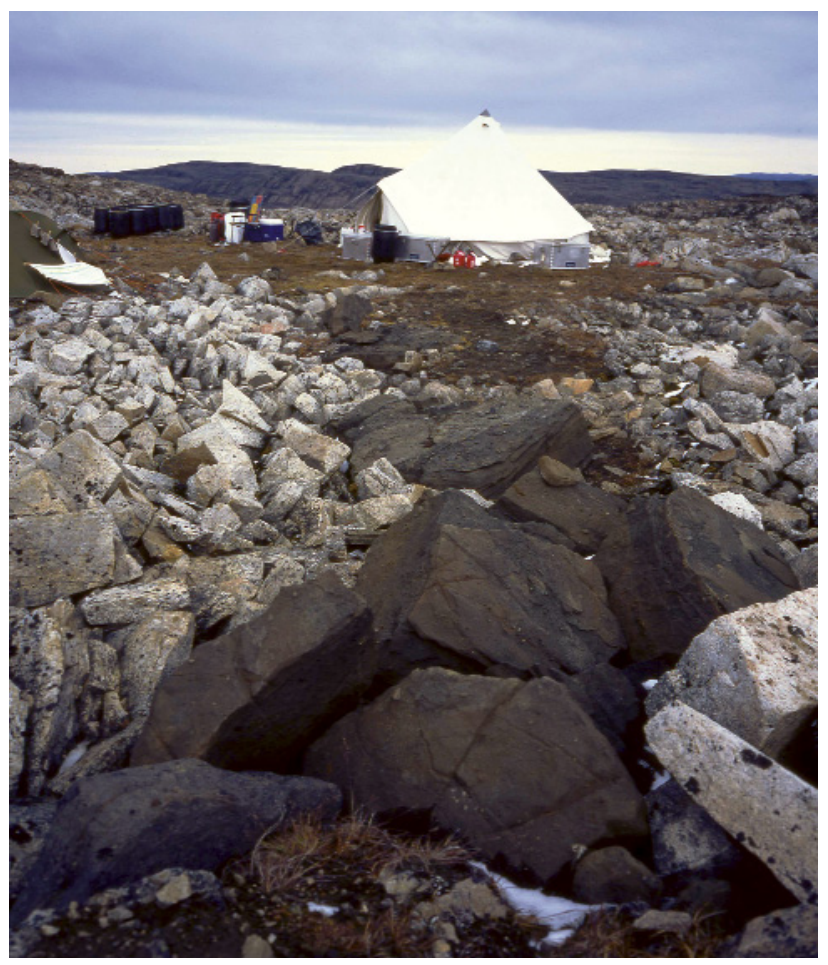

Fig. 4. Boulders of a $1.5 \mathrm{~m}$ wide and $2500 \mathrm{~m}$ long dyke sampled for testing for diamond content (Area 3 in Fig. 1). 
Indicator minerals from the same three kimberlitic occurrences have been separated, picked and analysed by electron microprobe. The indicator minerals studied are sub-calcic pyrope, eclogitic garnet, chrome-diopside, chromite, ilmenite and olivine. The indicator mineral chemistry will be used in conjunction with the diamond determination results to assess the diamond potential of the occurrences. The mineral chemistry fingerprint of the in situ occurrences may have important implications for the interpretation of existing indicator mineral chemistry data from till and stream sediment samples.

\section{Research in progress}

The field work in 2003 included detailed magnetic mapping of the three occurrences using a proton magnetometer. Interpretation of the geophysical field data is ongoing.

Petrographic and geochemical characterisation of the kimberlitic occurrences has been largely neglected in previous investigations, and accordingly a comprehensive programme to systematically study and classify the groundmass, mantle xenoliths and indicator minerals of these rocks has been initiated.

An extensive programme to determine the age of these and many additional kimberlitic occurrences using the very precise U-Pb in perovskite method (e.g. Heaman et al. 2003) has been launched. Some phlogopite-rich rocks will be dated by the Rb-Sr method. A total of around 35 age determinations have been commissioned.

An updated version of the digital data compilation (Jensen et al. 2003a) planned for 2004 will include the results of the ongoing Survey testing and analytical work, as well as recently released company data, amounting to 3300 pages of text, tables and maps, 50000 indicator mineral analyses, around 100 previously undescribed kimberlitic occurrences and a large volume of airborne geophysical data.

\section{Acknowledgement}

The work reported on here has been supported and financed in part by the Bureau of Minerals and Petroleum in Nuuk.

\section{References}

Boucher, D.R. 2000: 1999 Assessment work report on the mini-bulk sampling programme, Sarfartoq exploration licence, Kalaallit Nunaat, 18 pp. Unpublished report, Monopros Ltd. for Dia Met Minerals Ltd., Kelowna, B.C., Canada (in archives of the Geological Survey of Denmark and Greenland, GEUS Report File 21742).
Escher, A., Escher, J.C. \& Watterson, J. 1970: The Nagssugtoqidian boundary and the deformation of the Kângamiut dyke swarm in the Søndre Strømfjord area. Rapport Grønlands Geologiske Undersøgelse 28 21-23.

Escher, A., Sørensen, H. \& Zeck, H.P. 1976: Nagssugtoqidian mobile belt in West Greenland. In: Escher, A. \& Watt, W.S. (eds): Geology of Greenland, 76-103. Copenhagen: Geological Survey of Greenland.

Heaman, L.M., Kjarsgaard, B.A. \& Creaser, R.A. 2003: The timing of kimberlite magmatism in North America: implications for global kimberlite genesis and diamond exploration. Lithos 71, 153-184.

Jensen, S.M., Hansen, H., Secher, K., Steenfelt, A., Schjøth, F. \& Rasmussen, T.M. 2002: Kimberlites and other ultramafic alkaline rocks in the Sisimiut-Kangerlussuaq region, southern West Greenland. Geology of Greenland Survey Bulletin 191, 57-66.

Jensen, S.M., Lind, M., Rasmussen, T.M., Schjøth, F. \& Secher, K. 2003a: Diamond exploration data from West Greenland. Danmarks og Grønlands Geologiske Undersøgelse Rapport 2003/21, 50 pp. + 1 DVD.

Jensen, S.M., Secher, K., Rasmussen, T.M., Tukiainen, T., Krebs, J.D. \& Schjøth, F. 2003b: Distribution and magnetic signatures of kimberlitic rocks in the Sarfartoq region, southern West Greenland. 8th International Kimberlite Conference, Victoria, B.C., Canada. Extended abstracts CD-ROM, 5 pp.

Jensen, S.M., Secher, K., Rasmussen, T.M., Tukiainen, T., Krebs, J.D. \& Schjøth, F. 2003c: Distribution and magnetic signatures of kimberlitic rocks in the Sarfartoq region, southern West Greenland. 8th International Kimberlite Conference, Victoria, B.C., Canada. Poster presentation [available as PDF on CD-ROM from authors].

Jensen, S.M., Secher, K. \& Rasmussen, T.M. 2004: Diamond content of three kimberlitic occurrences in southern West Greenland. Diamond identification results, field description and magnetic profiling. Danmarks og Grønlands Geologiske Undersøgelse Rapport 2004/19, $41 \mathrm{pp}$.

Larsen, L.M. 1980: Lamprophyric and kimberlitic dykes associated with the Sarfartôq carbonatite complex, southern West Greenland. Rapport Grønlands Geologiske Undersøgelse 100, 65-69.

Larsen, L.M. 1991: Occurrences of kimberlite, lamproite and ultramafic lamprophyre in Greenland. Open File Series Grønlands Geologiske Undersøgelse $\mathbf{9 1 / 2}, 36$ pp.

Larsen, L.M. \& Rex, D.C. 1992: A review of the 2500 Ma span of alkalineultramafic, potassic and carbonatitic magmatism in West Greenland. Lithos 28, 367-402.

Mitchell, R.H., Scott Smith, B.H. \& Larsen, L.M. 1999: Mineralogy of ultramafic dikes from the Sarfartoq, Sisimiut and Maniitsoq areas, West Greenland. In: Gurney, J.J. et al. (eds): Proceedings of the VIIth International Kimberlite Conference 2, 574-583. Cape Town: Red Roof Design cc.

Rombouts, L. 1995: Sampling and statistical evaluation of diamond deposits. In: Griffin, W.L. (ed.): Diamond exploration into the 21st century. Journal of Geochemical Exploration 53(1-3), 351-367.

Scott, B.H. 1981: Kimberlite and lamproite dykes from Holsteinsborg, West Greenland. Meddelelser om Grønland, Geoscience 4, 24 pp.

Secher, K. \& Larsen, L.M. 1980: Geology and mineralogy of the Sarfartôq carbonatite complex, southern West Greenland. Lithos 13, 199-212.

Tuer, J. 2003: Hudson announces diamond results for West Greenland program. News Release NR2003-5, 1 p. Vancouver, Canada: Hudson Resources Inc. (issued 1 October 2003).

\footnotetext{
Authors' address

Geological Survey of Denmark and Greenland, Øster Voldgade 10, DK-1350 Copenhagen K, Denmark. E-mail: smj@geus.dk
} 